Jean Didier Tèwogbade AKPONA ${ }^{1}$ Achille Ephrem Assog BADJO ${ }^{1,2}$ Adandé Belarmain FANDOHAN ${ }^{1,2,3}$ Romain GLÈLÈ KAKAï ${ }^{1}$

${ }^{1}$ Université d'Abomey-Calavi Faculté des Sciences Agronomiques Laboratoire de Biomathématiques et d'Estimations Forestières (UAC/FSA/LABEF) 05 BP 1752, Cotonou

Bénin

2 Université d'Abomey-Calavi

Faculté des Sciences Agronomiques Laboratoire d’Écologie Appliquée (LEA)

(UAC/FSA/LEA)

05 BP 1752, Cotonou

Bénin

3 Université d’Agriculture de Kétou École de foresterie et ingénierie du bois Unité de recherche en foresterie, agroforesterie et biogéographie BP 43, Kétou

Bénin

\title{
Inventory and multicriteria approach to identify priority commercial timber species for conservation in Benin
}

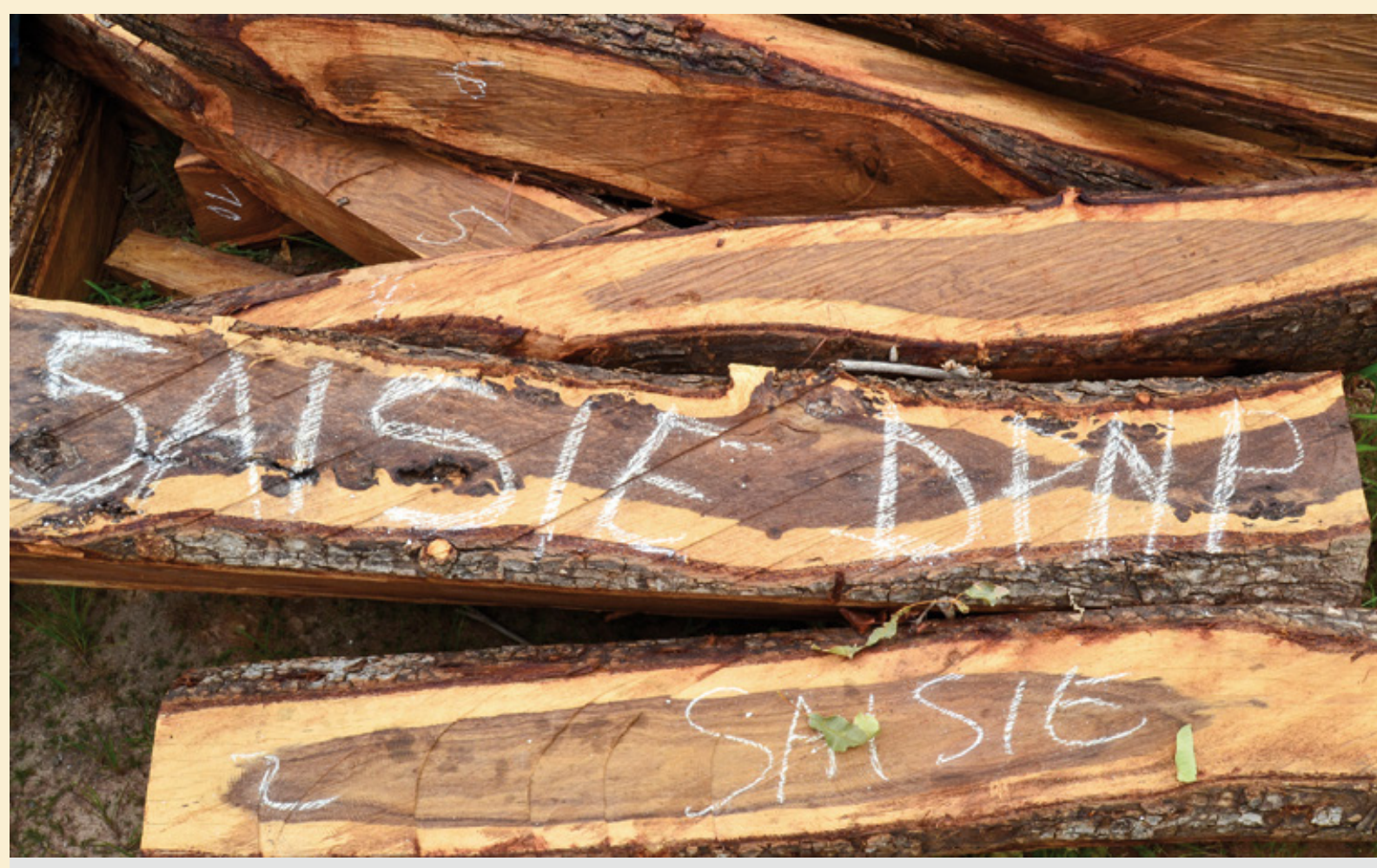

Photo 1.

Wood of Pterocarpus erinaceus logged in Pendjari Biosphere Reserve.

Photo J. D. T. Akpona. 


\section{RÉSUMÉ}

\section{INVENTAIRE ET APPROCHE MULTICRITĖRES POUR IDENTIFIER LES ESSENCES PRIORITAIRES POUR LA CONSERVATION AU BÉNIN}

Diverses essences forestières, dont certaines sont menacées, sont exploitées pour leur bois, légalement ou non. Les essences prioritaires pour la conservation à long terme doivent donc être définies. La présente étude a permis de réaliser un inventaire des essences exploitées au Bénin et d'identifier les essences prioritaires pour lesquelles des actions urgentes de conservation et de restauration sont nécessaires. Des recherches bibliographiques complétées par des entretiens avec différentes parties prenantes ont été menées afin de recueillir les données requises pour dresser une liste exhaustive des essences prioritaires. Dix critères et quatre méthodes de priorisation ont été utilisés. Au final, l'approche a retenu 10 essences parmi les 15 essences prioritaires définies par chacune des méthodes. Au total, 24 espèces végétales ont été identifiées, appartenant à 9 familles : Fabacées (25\%), Malvacées (20,83\%), Méliacées (16,67\%), Combrétacées (8,33\%), Moracées (8,33\%), Verbénacées (8,33\%), Ébénacées (4,17\%), Rutacées $(4,17 \%)$ et Myrtacées (4,17\%). Des mesures de conservation et de restauration sont préconisées d'urgence pour les 10 essences prioritaires ainsi retenues.

Mots-clés : essences forestières, conservation, méthodes de priorisation, Afrique de l'Ouest.

\section{ABSTRACT}

\section{INVENTORY AND MULTICRITERIA APPROACH TO IDENTIFY PRIORITY COMMERCIAL TIMBER SPECIES FOR CONSERVATION IN BENIN}

A variety of timber species, some of which are under threat, are targets for both legal and illegal logging. Priority timber species for long-term conservation therefore need to be defined. This study produced an inventory of timber species logged in Benin and defined priority Timber Species (TS) requiring urgent conservation and restoration measures. Data to establish an exhaustive list of TS in Benin were collected through a review of the literature and interviews with different stakeholders. Ten criteria were applied to four different prioritization methods. The top 15 species obtained with each of these methods were identified and the top 10 were shortlisted. A total of 24 plant species belonging to nine families were identified. Those most represented were: Fabaceae (25\%), Malvaceae (20.83\%), Meliaceae (16.67\%), Combretaceae (8.33\%), Moraceae (8.33\%), Verbenaceae $(8.33 \%)$, Ebenaceae ( $4.17 \%)$, Rutaceae $(4.17 \%)$ and Myrtaceae $(4.17 \%)$. The ten top species deserve urgent conservation and restoration measures.

Keywords: timber species, conservation, prioritization methods, West Africa.

\section{RESUMEN}

\section{INVENTARIO Y ENFOQUE MULTICRITERIO PARA IDENTIFICAR LAS ESPECIES MADERABLES COMERCIALES PRIORITARIAS PARA LA CONSERVACIÓN EN BENÍN}

Diversas especies forestales, algunas de ellas en peligro, son objeto de explotación maderera legal e ilegal. Hay que definir las especies prioritarias para su conservación a largo plazo. Este estudio permitió realizar un inventario de las especies madereras explotadas en Benín y priorizar aquellas que requieren medidas urgentes de conservación y restauración. Se efectuó una investigación bibliográfica, completada con entrevistas a las distintas partes interesadas, a fin de recopilar los datos necesarios para elaborar una lista exhaustiva de especies prioritarias. Se utilizaron diez criterios y cuatro métodos de priorización. Al final, el enfoque permitió seleccionar 10 de las 15 especies prioritarias obtenidas con cada uno de los métodos. Se identificaron un total de 24 especies vegetales pertenecientes a 9 familias: Fabáceas (25\%), Malváceas (20,83\%), Meliáceas (16,67\%), Combretáceas (8,33\%), Moráceas $(8,33 \%)$, Verbenáceas $(8,33 \%)$, Ebenáceas $(4,17 \%)$, Rutáceas $(4,17 \%)$ y Mirtáceas $(4,17 \%)$. Se recomiendan medidas urgentes de conservación y restauración para las 10 especies prioritarias seleccionadas.

Palabras clave: especies forestales, conservación, métodos de priorización, África Occidental. 


\section{Introduction}

In several regions of the tropics, timber species are harvested at rates that are far beyond their rhythm of regeneration. These species are preferred by people as the first interest is timber for building material, lumber, etc. and can have other uses for people. It was showcased that, in all International Tropical Timber Organization (ITTO) member countries, only $3.5 \%$ of permanent forest estates are sustainably managed (ITTO, 2007). In most developing countries, untrained and unsupervised tree fellers and skidder drivers are used for legal and illegal logging and they often work without planned paths of log extraction, and without financial incentives to reduce the negative environmental impacts of their activities (ITTO, 2007). According to Putz (1991), even at low harvesting intensities (e.g., < 5 trees extracted per hectare), forests lose much of their sylviculture value due to soil damage and damage to future crop trees, coupled with the increased livelihood of invasion by lianas and alien species.

Benin is a moderately forested country with vegetation dominated by savanna mosaics whereby degradation of forests is still a major concern. According to FAO (2011), the forest cover is estimated at 4,511,000 ha, which represents $40 \%$ of the country total area. Yet, recent investigations show that Benin loses 50,000 hectares of natural forest in average yearly (FAO, 2011). Illegal tree felling, land clearing for agriculture, bushfires, charcoal production and overgrazing are often referred to as the main drivers of forest degradation and destruction in Benin. This has resulted in decline of the populations of many economically important indigenous timber species (Dimobe et al., 2014). Developing sylvicultural packages to guide reforestation and/or forest enrichment is necessary to ensure conservation and sustainability use of these species. In Benin, several species are used for timber and few studies have been focused on the commercial timber species and identifying priority species for conservation. People have developed specific choice criteria for choosing timber species so that when one species becomes rare, they move to another one more abundant. This process negatively impacts biodiversity conservation. Since all species cannot be focused on at once, prioritization is necessary to select the most important species that need urgent conservation effort. This prioritization informs a wide array of conservation decisions and can help for decision-making.

Establishing priorities for conservation is an obvious and key step to designing a realistic and efficient conservation strategy. According to Magos Brehm et al. (2010), species prioritization is particularly important when the focus is the conservation of socio-economically important species and prioritization for conservation can be undertaken at different levels (species, ecosystem, etc.). It allows conservation managers to know which species are not priorities and which have information gaps to be filled (Idohou et al., 2013). Different methods of prioritization based on range, habitat specificity and local abundance have been described (Rabinowitz et al., 1986). There has been considerable debate over which criteria should be considered when prioritizing species for conservation (see Maxted et al., 1997). Magos Brehm et al. (2010) proposed various criteria and different prioritization schemes. Their methodology has recently been used to set priorities for crop wild relatives in Benin (Idohou et al., 2013) as well as medicinal tree species (Yaoitcha et al., 2015). Developing an innovative prioritization scheme and making use of the available data so as to identify priority TS for conservation in order to establish a national timber conservation strategy is the main goal of this study. Two questions were asked: What is the diversity of commercial timber species in Benin? And, which species need urgent priority conservation at national scale? It stands as a useful case study that establishes a national list of logged timber species in Benin and highlights priority species for conservation.

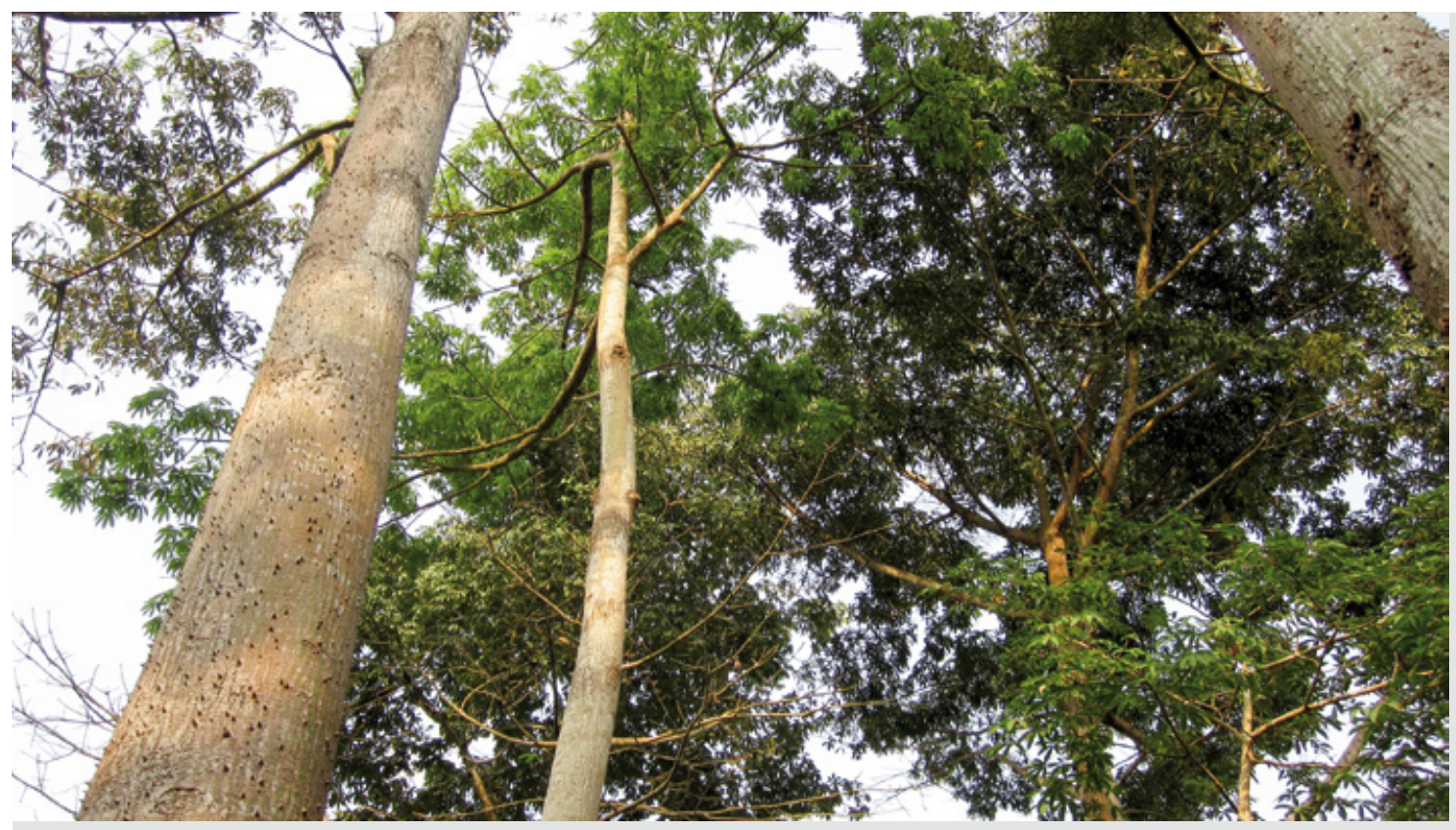

Photo 2.

Ceiba pentandra trees in Sacred Forest of Bonou.

Photo J. D. T. Akpona. 


\section{Materials and methods}

\section{Study area}

The study was carried out in the Republic of Benin, located between $6^{\circ} \mathrm{N}$ and $12^{\circ} 50^{\prime} \mathrm{N}$ and $1^{\circ} \mathrm{E}$ and $3^{\circ} 40^{\prime} \mathrm{E}$ in West Africa (Adomou, 2005). The study system encompasses three centres of plants endemism subdivided into ten phytogeographical districts: the Sudanian (Atacora Chain, Mekrou-Pendjari and Borgou-North districts), the Sudano-Guinean (South-Borgou, Bassila and Zou districts), the Guineo-Congolian (Coastal, Plateau, Pobè and Oueme Valley districts) (Adomou, 2005). The National flora is estimated at 2,807 species of plants divided into 1,129 genera and 185 families (Akoègninou et al., 2006). The ratio of timber species among the total number of species in the country is $8 \%$. Vegetation in the Guineo-Congolian centre is dominated by undifferentiated savanna mosaics, semi-deciduous forests and swamp forests. Isoberlinia-dominated woodlands and Acacia and Combretum-dominated savannas are the major vegetation types in the Soudano-Guinean and the Sudanian centre, respectively (White, 1983). Rainfall is bimodal in the Guineo-Congolian region but tends to be unimodal in the Sudano-Guinean and Sudanian region.

Generally, mean monthly temperatures oscillate between 26 and $30^{\circ} \mathrm{C}$ over the country with peaks of $35^{\circ} \mathrm{C}$ to $40^{\circ} \mathrm{C}$ in the dry season upmost north (Adomou, 2005). Since 1960 , forest exploitation has targeted several indigenous timber species of high economic (More than $64.600 \mathrm{~m}^{3}$ for a period of 5 years) and socio-cultural value: Milicia excelsa (Welw.) C.C. Berg, Triplochiton scleroxylon K. Schum., Khaya senegalensis (Desv.) A. Juss., Afzelia africana Sm. and Pterocarpus erinaceus Poir. While these species are faced with local extirpation, no silviculture package (tree establishment, growth, health and quality of forests to meet diverse needs and values) has been so far developed to promote their conservation and integration into national reforestation plan (Gogan, 2010).

\section{Inventory of marketable timber species in Benin}

The starting point for preparing a national timber conservation strategy is the inventory of logged species. First of all, a literature review was done in order to investigate the existing knowledge on species used as timber using especially the book “Flore du Bénin” (de Souza, 2008). Secondly, semi-structured interviews and focus group discussions were conducted among different stakeholders (sawyers, joiners, loggers, timber traders and wood industrials) involved in the timber sector over the three biogeographical zones of Benin.

The data collection phase took place between June and October 2013. Before starting the survey, prior informed consent was obtained from local leaders in the target zones. Detailed information of the study and its importance were provided to the leaders. An exploratory survey was conducted in two districts randomly chosen in each phytochorological zone: Tanguieta, Natitingou in the Sudanian zone; Bassila, Dassa in the Sudano-Guinean zone and Aplahoué,
Zogbodomey in the Guineo-Congolian zone. In each zone, 140 informants were asked if they are involved in the timber sector. The proportion ( $p$ ) of positive answers was used to compute the numbers ( $n$ ) of the individuals to be surveyed following Dagnelie (1998):

$\mathrm{n}=\frac{\mathrm{U}_{1-\alpha / 2}^{2} \times p(1-p)}{d^{2}}$

Where $\mathrm{n}$ is the sample size considered in the phytodistrict, $p$ is the proportion of stakeholders or interviewees that were involved in logging. The interviewees were asked if they are involved in logging.

- $U$ is the value of the Normal random variable at probability value of $1-\alpha / 2$.

For a probability value of 0.975 (or $\alpha=0.05$ ), $U_{1-\alpha / 2} \approx 1.96$; - $\mathrm{d}$ is the margin of error of the estimation of any parameter to be computed from the survey and a value of $5 \%$ was considered.

At the end, in order to have only one sample size, one proportion was considered by putting together the answers from each phytochorological zone. By computing with the formula above, the number of informants randomly considered for all the phytodistricts was 650 .

In each biogeographical zone, the informants were asked to list all timber species used as well as their specific usage types apart for timber. Data were collected using semi-structured interviews. Interviews were conducted orally with, sometimes, the assistance of a local translator. Different demographic parameters (gender, age, education, ethnicity, etc.) were collected before the listing of timber species.

\section{Setting priorities for timber species conservation}

The process of establishing priorities among a set of species is a first step in any conservation strategy (Maxted and Kell, 2009ab). The criteria used for the prioritization were adapted from those proposed by Magos Brehm et al. (2010) and used by Idohou et al. (2013). Ten criteria were used and described in the current study (table I).

\section{Prioritization approach}

Four different methods of combining the above mentioned ten criteria (figure 1) were adapted from Magos Brehm et al. (2010) and Idohou et al. (2013): point scoring procedure (PSP), point scoring procedure with weighting (PSPW), compound ranking system (CRS) and binomial ranking system (BRS).

In the PSP, the priority value of each reported species was computed as follows:

Score $1=\Sigma$ (native status + economic importance + ethnobotanical value + knowledge of technical routes + conservation status +global distribution + plasticity + legislation + international threat status + national threat status) 
Table I.

Criteria used for establishment of priority timber species for conservation with their different levels or modalities.

\begin{tabular}{|c|c|}
\hline Criteria & Description \\
\hline Origin of the species & $\begin{array}{l}\text { Since the inventory has native, introduced and unknown/ } \\
\text { doubtful origin species, priority was given to species } \\
\text { belonging to the natural flora of Benin (indigenous species). }\end{array}$ \\
\hline Economic importance & $\begin{array}{l}\text { We collected information from forest administration on the } \\
\text { cubage meters of each species exploited and the list of } \\
\text { species used at local, national, regional and international } \\
\text { market. }\end{array}$ \\
\hline Ethnobotanical value & $\begin{array}{l}\text { This was assessed through local knowledge on the uses of } \\
\text { the species. Priority was given to the species having higher } \\
\text { importance for local people in the number of uses listed. }\end{array}$ \\
\hline $\begin{array}{l}\text { Knowledge of technical } \\
\text { routes of production }\end{array}$ & $\begin{array}{l}\text { Introduction of native species in reforestation plan requires } \\
\text { a strong knowledge of germination and seedling growth. } \\
\text { Priority was given to species with no silviculture package. }\end{array}$ \\
\hline Global distribution & $\begin{array}{l}\text { Priority decreases with larger distribution; therefore, } \\
\text { nationally- or regionally- restricted species (or endemics) } \\
\text { were given more priority than species occurring worldwide. }\end{array}$ \\
\hline National distribution & $\begin{array}{l}\text { A species occurring in a few provinces and in a few } \\
\text { ecological condition was considered rarer than a species } \\
\text { occurring throughout the country and can be established } \\
\text { in different ecological conditions. }\end{array}$ \\
\hline Conservation status & $\begin{array}{l}\text { The existing conservation strategy or not were considered. } \\
\text { Data were collected from thesis, books and articles. }\end{array}$ \\
\hline Legislation & $\begin{array}{l}\text { Priorities for conservation are given to species listed in } \\
\text { national/international legislation (Magos Brehm et al., } \\
\text { 2010). }\end{array}$ \\
\hline Threats assessments & $\begin{array}{l}\text { IUCN Red List as well as Benin Red List of threatened } \\
\text { species were used. }\end{array}$ \\
\hline
\end{tabular}

\section{Modalities}

Three modalities were considered: (a) indigenous, (b) introduced, (c) No data/doubt.

Four levels were considered: local, regional, national and international. Priority was given to the species having higher economic importance.

The categories considered: (a) 1 use, (b) 2 uses, (c) 3 uses, (d) 4 uses, (e) 5 uses, (f) 6 uses, (g) 7 uses, (h) 8 uses, (i) No data.

Two categories were considered: (a) silviculture known, (b) silviculture not known.

The categories considered were the distribution at the level of: (a) Est Africa/West Africa/North/South/Center , (b) Throughout Africa, (c) World, (d) No data.

Flora of Benin was used. These level were considered (a) 1, (b) 2, (c) 3, (d) 4, (e) 5, (f) 6, (g) 7, (h) 8, (i) 9, (j) 10, (k) No data.

The categories concerned were: (a) conservation Protected (b) Non protected.

The categories are: (a) Decree $N^{\circ} 96-271$ of 2 July 1996 of the Law 93-009 related to forest regime in Republic of Benin, (b) international convention CITES, (c) No data.

The categories are: (a) EN, (b) NE, (c) VU, (d) LC, (e) NT, (f) NF.

This methodology was adapted from Bhrem et al. (2010) and Idohou et al. (2013).

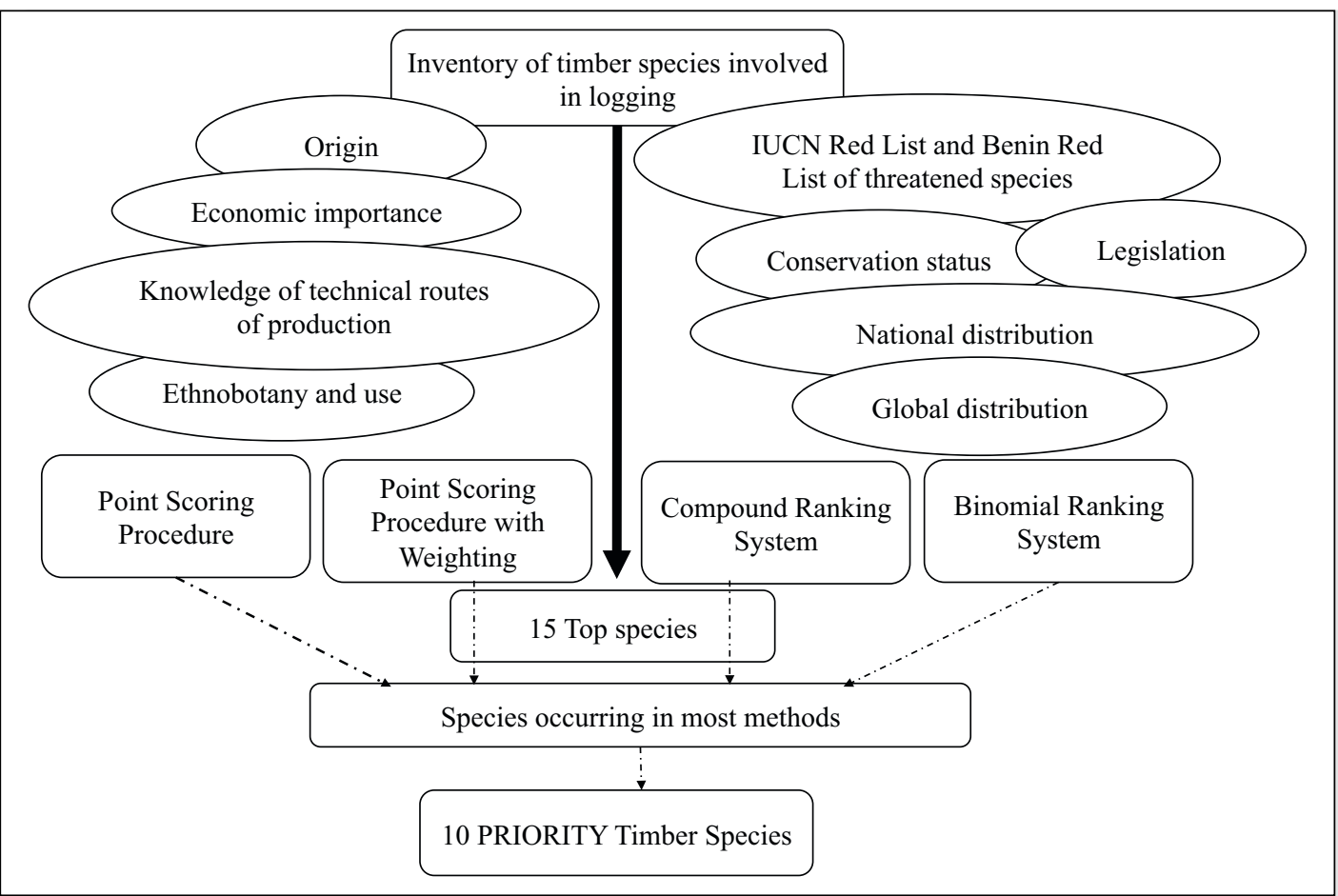

Figure 1.

Methodology used for establishing conservation priorities for timber species in Benin, Adapted from Magos Brehm et al. (2010). 
The above formula was combined with specific weight (Magos Brehm et al., 2010) for each criterion to get the PSPW approach:

Score $2=\Sigma\{0.15$ (native status) +0.075 (economic importance $)+0.05$ (ethnobotanical value $)+0.075$ (knowledge of technical routes) +0.1 (conseration status $)+0.15$ (global distribution $)+0.1$ (plasticity) +0.1 (legislation) +0.1 (international threatened status) +0.1 (national threatened status)\}

For the CRS approach, the rank varied between 1 to $n$ (number of the criterion).

The total ranking is obtained by summing individual ranks of each criterion (see Magos Brehm et al., 2010).

Total rank $=\sum_{i}^{n}=\alpha R \beta$

$\alpha$ represent the coefficient of the rank $(R)$ and $\beta$ represent the index of the rank.

From this ranking perceptive, we could not derive priorities species. So, we got scores from those ranks as follows: Score $3=(\alpha 1 * \beta 1)+\left(\alpha 2^{\star} \beta 2\right)+\ldots+\left(\alpha n^{\star} \beta n\right)$

Considering the score rank by each species, priorities were given to decreasing value of the score.

For the BRS method, binomial approach was used with value 1 if the criterion is verified and 0 otherwise. The score is obtained as follows:

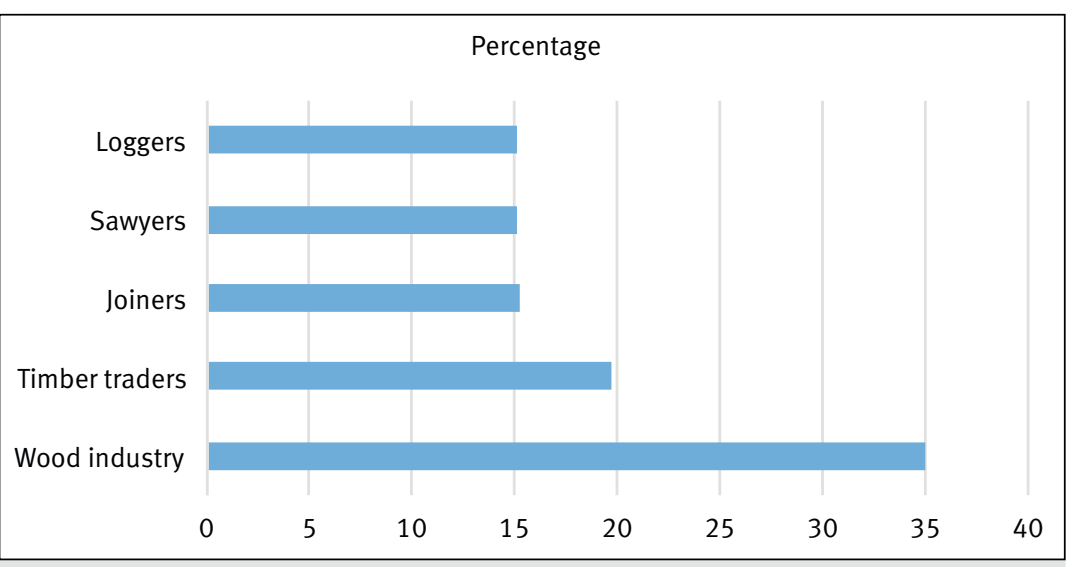

Figure 2.

Percentage of respondents involved in the activity.

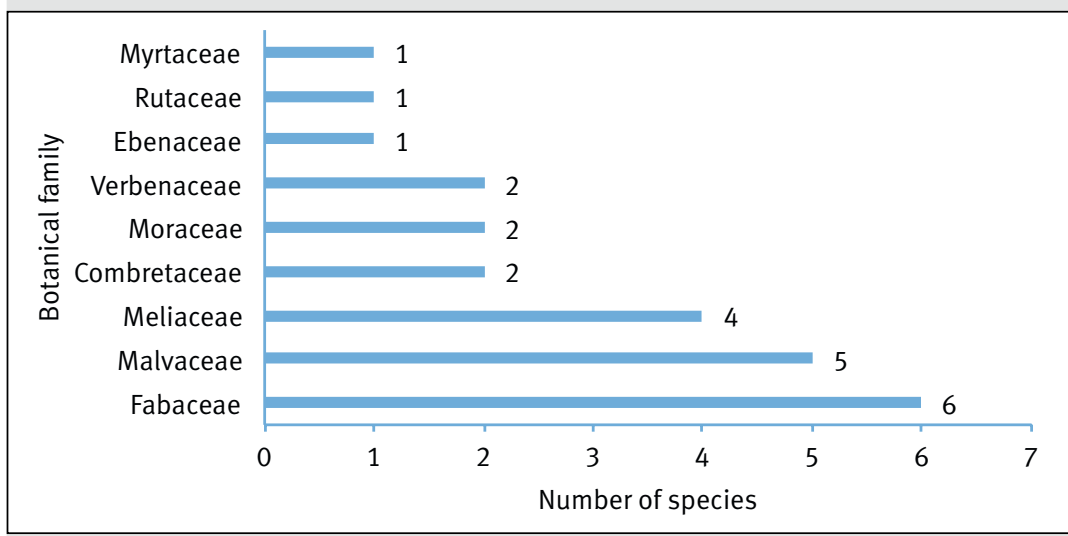

Figure 3.

Number of commercial timber species per family in Benin.
Score $4=\Sigma$ (native status + economic importance + ethnobotanical value + knowledge of technical routes + conservation status + global distribution + plasticity + legislation + international threat status + national threat status)

Using the abovementioned different approaches, the top 15 selected species were the same across the four prioritization methods with the same ranking (PSP, PSPW, CRS and BRS). To identify the most important timber species for conservation in Benin, the new score was affected to each species in each method used by order of appearing of each species in each of the methods.

\section{Results}

\section{Socio-demographic characteristics of interviewees}

The interviewees were mostly men (96.43\%). A categorization of surveyed people according to age, educational level and seniority showed that all interviewees are mostly adults ( $81.43 \%)$; and their level of education range from primary $(10.38 \%)$ to secondary school $(69.29 \%)$. There were two main groups in terms of seniority in the timber sector, namely: those who have been involved for less than ten years (46.43\%), and those who have been involved over ten years (14.29\%). A total of 18 socio-cultural groups were represented with the top three being Fon (28.57\%), Nago (13.57\%) and Bariba (12.15\%). Surveyed people were mainly from five specialties (profession): sawyers, joiners, wood industry, logger, timber traders (figure 2).

\section{Priority timber species for active conservation}

Twenty four species belonging to nine families were recorded. The three most represented families are the Fabaceae (25\%) with six species: A. africana, Daniellia oliveri (Rolfe) Hutch. \& Dalz., Isoberlinia doka Craib \& Stapf, Isoberlinia tomentosa (Harms) Craib \& Stapf., Prosopis africana Guill. et Perr., P. erinaceus; Malvaceae (20.83\%), five species: Bombax costatum Pellegr. \& Vuillet., Ceiba pentandra (L.) Gaertn., Cola cordifolia (Cav.) R. Br., Cola gigantean A. Chev., T. scleroxylon and Meliaceae (16.67\%), four species: Azadirachta indica A. Juss., Khaya grandifoliola C. DC., K. senegalensis, Pseudocedrala kotschyi (Schweinf.) Harms (figure 3). These species were used for other purposes including firewood, art and sculpture, food and medicine (table II).

The top 10 species were those who reached the highest score (table III). For the PSP and PSPW methods, the five top prioritized species were: $K$. senegalensis, $K$. grandifoliola, P. kotschyi (Meliaceae), A. africana 
(Fabaceae) and M. excelsa (Moraceae). For the CRS method, the top species were $K$. senegalensis, $K$. grandifoliola, $A$. africana, $P$. erinaceus and $M$. excelsa. Finally, for the BRS method, the top species were $A$. africana, $K$. senegalensis, K. grandifoliola, M. excelsa and P. erinaceus. Two species appeared at the top, whatever the method used: $K$. senegalensis and $K$. grandifoliola. From this ranking results, $K$. senegalensis could be considered the most important species for active conservation in Benin.

Table II.

Family diversity and derived products of timber species.

\begin{tabular}{|c|c|c|c|c|}
\hline $\begin{array}{l}\text { Botanical } \\
\text { family }\end{array}$ & Species & Common name & Derived Product & Uses \\
\hline \multirow[t]{5}{*}{ Malvaceae } & Bombax costatum Pellegr. \& Vuillet & Faux-Kapokier ${ }^{\mathrm{a}}$ & Formwork & 1 \\
\hline & Ceiba pentandra (L.) Gaert. & $\begin{array}{l}\text { Fromager }^{\mathrm{a}}, \text { wutin }^{\mathrm{b}} \text {, } \\
\text { agugu }^{\mathrm{d}} \text { secma }^{\mathrm{e}} \mathrm{Aaba}^{\mathrm{d}}\end{array}$ & Formwork, pirogues & 1,3 \\
\hline & Cola cordifolia (Cav.) R. Br. & Wutin wi ${ }^{\mathrm{b}}$ & Formwork & 1,2 \\
\hline & Cola gigantea A. Chev. & Wutin ${ }^{\mathrm{b}}$ & Formwork & 1 \\
\hline & Triplochiton scleroxylon K. Schum & Samba ${ }^{a}$, Arere $^{d}$ & Wooden furniture, doors, windows & 1,4 \\
\hline \multirow[t]{2}{*}{ Combretaceae } & Anogeissus leiocarpa (DC.) Guill. \& Perr. & $\begin{array}{l}\text { Hlihon }^{\mathrm{b}} \text {, kakalac, ayin } \\
\text { kolo }^{\mathrm{d}} \text {, } \\
\text {, agbanga }\end{array}$ & Chevrons & 1,2 \\
\hline & Terminalia glaucesens. Planch. ex Benth. & Alotu $^{b}, k_{p o b a}$ & Wooden tools, tool handles (brooms, hoes) & 1,3 \\
\hline Ebenaceae & Diospyros mespiliformis Hochst. ex A. DC. & $\begin{array}{l}\text { Ebene }^{\text {a }} \text {, kinwi }{ }^{b}, \text { donko } \\
\text { tokê }\end{array}$ & $\begin{array}{l}\text { Chevrons, joint covers ceilings, wooden } \\
\text { statues }\end{array}$ & $1,2,3$ \\
\hline \multirow[t]{6}{*}{ Fabaceae } & Afzelia africana $\mathrm{Sm}$. & $\begin{array}{l}\text { Linguéa }^{a} \text { kpakpadjidéb, } \\
\text { gbébou }^{c}, \text { akpaka }^{d}\end{array}$ & $\begin{array}{l}\text { Wooden furniture, doors, windows, frames, } \\
\text { statues }\end{array}$ & 1,3 \\
\hline & Daniellia oliveri (Rolfe) Hutch. \& Dalziel & $\begin{array}{l}\text { Zab, gnannou }{ }^{c}, \text { iya }^{d}, \\
\text { n'yobolo }^{\text {c }} \text {, ferma } \\
\end{array}$ & Shuttering for concrete, wooden seats & $1,2,3$ \\
\hline & Isoberlinia doka Craib \& Stapf & $\begin{array}{l}\text { Kpakpab, gbabac, } \\
\text { goutouchée }\end{array}$ & $\begin{array}{l}\text { Chevrons, joint covers, ceilings frame, } \\
\text { school furniture }\end{array}$ & 1,2 \\
\hline & $\begin{array}{l}\text { Isoberlinia tomentosa (Harms) } \\
\text { Craib \& Stapf }\end{array}$ & $\begin{array}{l}\text { Kpakpab, gbabac, } \\
\text { goutouchée }\end{array}$ & $\begin{array}{l}\text { Chevrons, joint covers ceilings frame, } \\
\text { school furniture }\end{array}$ & 1,2 \\
\hline & Prosopis africana (Guill. \& Perr.) Taub. & $\begin{array}{l}\text { Kakê }{ }^{\mathrm{b}} \text {, woure } \\
\text { dédjitouhouris }\end{array}$ & Mortars & 1,3 \\
\hline & Pterocarpus erinaceus Poir. & $\begin{array}{l}\text { Ven }^{a}, \text { kosso }^{b}, \text { tonan } / \text { toro }^{c} \\
\text { osun dudu }\end{array}$ & $\begin{array}{l}\text { Wooden furniture, school furniture, doors, } \\
\text { windows, frames, statuettes, ornaments } \\
\text { objects, tables }\end{array}$ & $1,3,4$ \\
\hline \multirow[t]{4}{*}{ Meliaceae } & Azadirachta indica A. Juss. & Neem $^{a}$, kinintin ${ }^{b}$ & Wooden tools, tool handles (brooms, hoes...) & 1,2 \\
\hline & Khaya grandifoliola C. DC. & faux acadjou ${ }^{\mathrm{a}}$ & $\begin{array}{l}\text { School furniture, wooden tables frames, doors, } \\
\text { windows ... }\end{array}$ & $1,2,4$ \\
\hline & Khaya senegalensis (Desv.) A. Juss. & $\begin{array}{l}\text { Calceidrat }{ }^{\mathrm{a}}, \text { acadjou }^{\mathrm{b}} \text {, } \\
\text { fele }^{\mathrm{c}}\end{array}$ & $\begin{array}{l}\text { School furniture, door and their frames, } \\
\text { windows }\end{array}$ & $1,2,3,4$ \\
\hline & Pseudocedrala kotschyi (Schweinf.) Harms & Tchagliglib $^{b}$ & School furniture & 1 \\
\hline \multirow[t]{2}{*}{ Moraceae } & $\begin{array}{l}\text { Antiaris toxicaria Lesch. subsp. } \\
\text { welwitschii (Engler) }\end{array}$ & Faux iroko ${ }^{a}$, ororo ${ }^{f}$ & Formwork & 1,2 \\
\hline & Milicia excelsa (Welw.) C.C. Berg & Iroko ${ }^{a}$, loko $^{b}$ & Framework, craft, seats & $1,2,3$ \\
\hline \multirow[t]{2}{*}{ Verbenaceae } & Gmelina arborea Roxb. & Faux teck & Wooden furniture, formwork, beds & $1,2,3$ \\
\hline & Tectona grandis L.f. & Teck $^{\mathrm{a}}$ & $\begin{array}{l}\text { Wooden furniture, statuettes, } \\
\text { ornaments wooden objects }\end{array}$ & $1,2,3$ \\
\hline Rutaceae & $\begin{array}{l}\text { Zanthoxylum zanthoxyloides (Lam.) } \\
\text { Zepem. \& Timler }\end{array}$ & Fagara $^{a}$, ata ${ }^{d}$ & Wooden furniture, doors, windows & 1,4 \\
\hline Myrtaceae & Eucalyptus camaldulensis Dehnh. & & Chevrons, other items, wooden ornaments & 1,4 \\
\hline
\end{tabular}


Table III.

List of the top 10 priority timber species for active conservation and sylviculture in Benin, obtaining by combining four different priority methods.

\begin{tabular}{|c|c|c|c|c|c|c|}
\hline Species & PSP & PSPW & CRS & BRS & Total & Scoring \\
\hline Khaya senegalensis (Desv.) A. Juss. & $\times$ & $\times$ & $x$ & $x$ & 4 & 60 \\
\hline Khaya grandifoliola C. DC. & $x$ & $x$ & $x$ & $x$ & 4 & 56 \\
\hline Afzelia africana $\mathrm{Sm}$. & $x$ & $x$ & $x$ & $x$ & 4 & 54 \\
\hline Milicia excelsa (Welw.) C.C. Berg & $x$ & $x$ & $x$ & $\times$ & 4 & 48 \\
\hline Pterocarpus erinaceus Poir. & $x$ & $x$ & $x$ & $x$ & 4 & 42 \\
\hline Isoberlinia tomentosa (Harms) Craib \& Stapf & $x$ & $\times$ & $\times$ & $\times$ & 4 & 34 \\
\hline Antiaris toxicaria Lesch. subsp. welwitschii (Engler) & $x$ & $x$ & $x$ & $x$ & 4 & 30 \\
\hline Anogeissus leiocarpa (DC.) Guill. \& Perr. & $\times$ & $\times$ & $\times$ & $x$ & 4 & 28 \\
\hline Pseudocedrela kotschyi (Schweinf.) Harms & $x$ & $\times$ & $\times$ & $x$ & 4 & 27 \\
\hline Isoberlinia doka Craib \& Stapf & $x$ & $x$ & $x$ & $x$ & 4 & 26 \\
\hline
\end{tabular}

\section{Table IV.}

Ethnobotanical uses, national distribution and threats of the most prioritized timber species.

\begin{tabular}{|c|c|c|c|c|c|}
\hline Species & Uses & $\begin{array}{l}\text { National } \\
\text { distribution }\end{array}$ & National Legislation & $\begin{array}{l}\text { Threats } \\
\text { assessment } \\
\text { (Adomou } \\
\text { et al., 2010) }\end{array}$ & $\begin{array}{l}\text { Threats } \\
\text { assessment } \\
\text { (IUCN } \\
\text { Red List) }\end{array}$ \\
\hline $\begin{array}{l}\text { Khaya senegalensis (Desv.) } \\
\text { A. Juss. }\end{array}$ & Timber, medicinal use, food & 5 phytodistricts & Décret nº 96-271 du 2 juillet 1996 & EN & VU \\
\hline Khaya grandifoliola C. DC. & Timber, medicinal use, food & 3 phytodistricts & Décret nº 96-271 du 2 juillet 1996009 & EN & VU \\
\hline Afzelia africana $\mathrm{Sm}$. & $\begin{array}{l}\text { Medicinal, soil fertilization, } \\
\text { timber use, firewood }\end{array}$ & 6 phytodistricts & Décret nº 96-271 du 2 juillet 1996 & EN & VU \\
\hline Milicia excelsa (Welw.) C.C. Berg & $\begin{array}{l}\text { Ornamental, timber use, } \\
\text { medicinal use }\end{array}$ & 4 phytodistricts & Décret nº 96-271 du 2 juillet 1996 & EN & NT \\
\hline Pterocarpus erinaceus Poir. & $\begin{array}{l}\text { Medicinal, soil fertilization, } \\
\text { timber, firewood, Food }\end{array}$ & 6 phytodistricts & Décret nº 96-271 du 2 juillet 1996 & EN & NE \\
\hline $\begin{array}{l}\text { Isoberlinia tomentosa } \\
\text { (Harms) Craib \& Stapf }\end{array}$ & $\begin{array}{l}\text { Charcoal production, } \\
\text { timber use, firewood }\end{array}$ & 3 phytodistricts & No legislation & NE & NE \\
\hline $\begin{array}{l}\text { Antiaris toxicaria Lesch. } \\
\text { subsp. welwitschii (Engler) }\end{array}$ & Timber & 2 phytodistricts & No legislation & NE & NE \\
\hline $\begin{array}{l}\text { Anogeissus leiocarpa (DC.) } \\
\text { Guill. \& Perr. }\end{array}$ & $\begin{array}{l}\text { Timber, medicinal use, } \\
\text { firewood, Charcoal }\end{array}$ & 4 phytodistricts & Décret nº 96-271 du 2 juillet 1996 & NE & NE \\
\hline $\begin{array}{l}\text { Pseudocedrela kotschyi } \\
\text { (Schweinf.) Harms }\end{array}$ & Medicinal, firewood, timber & 3 phytodistricts & No legislation & NE & NE \\
\hline Isoberlinia doka Craib \& Stapf & Charcoal, timber, firewood & 4 phytodistricts & Décret nº 96-271 du 2 juillet 1996 & NE & LC \\
\hline
\end{tabular}




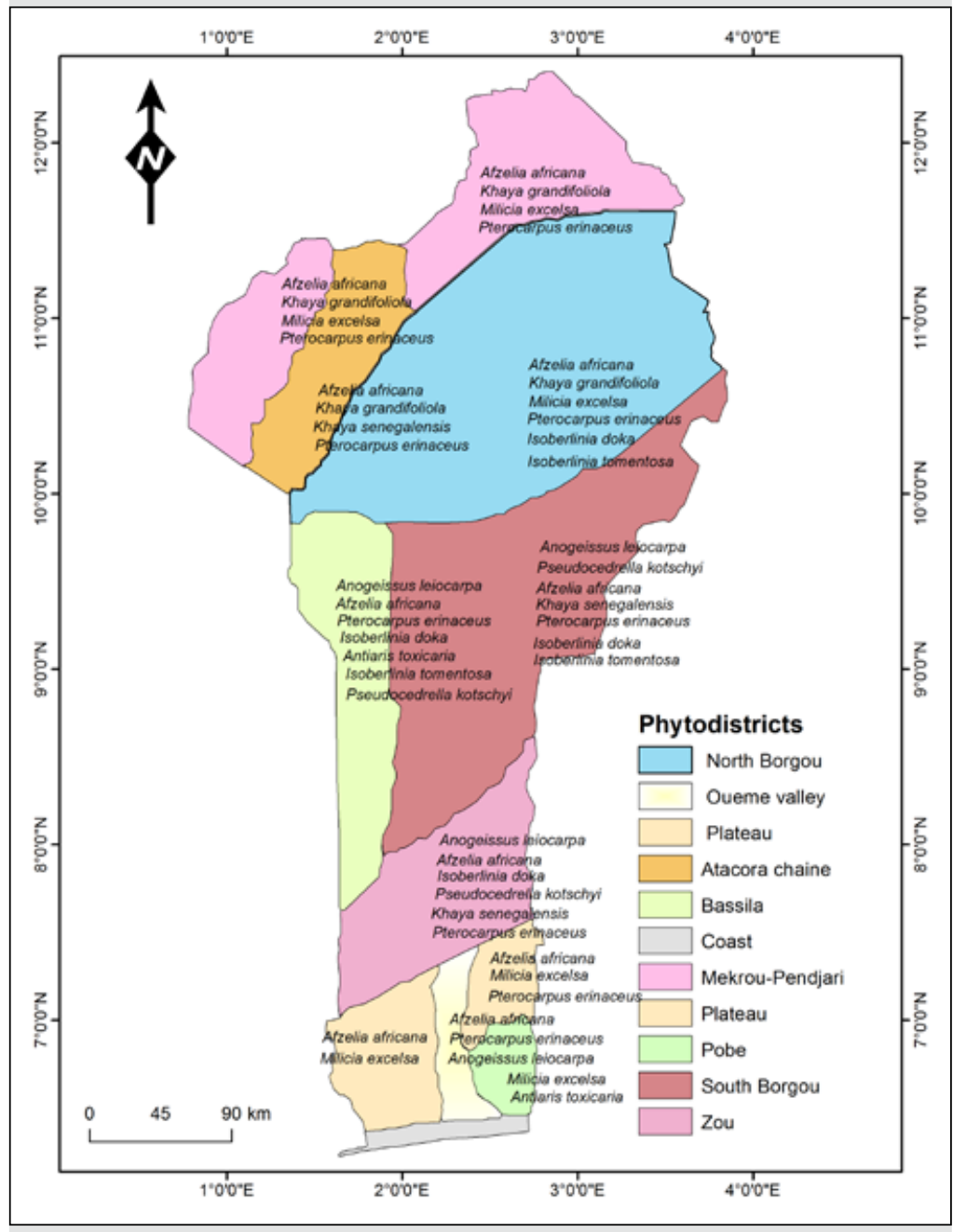

Figure 4.

Map of the Republic of Benin showing the phytogeographical districts and the occurrence of the most prioritized timber species.
In order of importance, the top ten species are listed in the table IV with their uses, national distribution and threats. Different uses were recorded for the top 10 timbers species. These uses were mostly timber, medicinal, food, charcoal and firewood. At national level, the "Décret n 96-271 du 2 juillet 1996" (law 93.009 related to forest regime in Republic of Benin) has targeted 7 species as protected. Some priority species are under this law. The top 10 timber species are distributed along the 10 phytodistricts. The most widely distributed species (figure 4) are $A$. africana and $P$. erinaceus (6 phytodistricts); $K$. senegalensis (5 phytodisctrits); M. excelsa, A. leiocarpa and I. doka (4 phytodistricts); $K$. grandifoliola, I. tomentosa and P. kotschyi (3 phytodistricts) and $A$. toxicaria (2 phytodistricts). According to the threat assessment, five species are endangered ( $K$. senegalensis, K. grandifoliola, A. africana, M. excelsa and $P$. erinaceus) and using IUCN red list (international), three species are vulnerable (K. senegalensis, K. grandifoliola, A. africana), one near threatened ( $M$. excelsa) and one of least concern (l. doka).

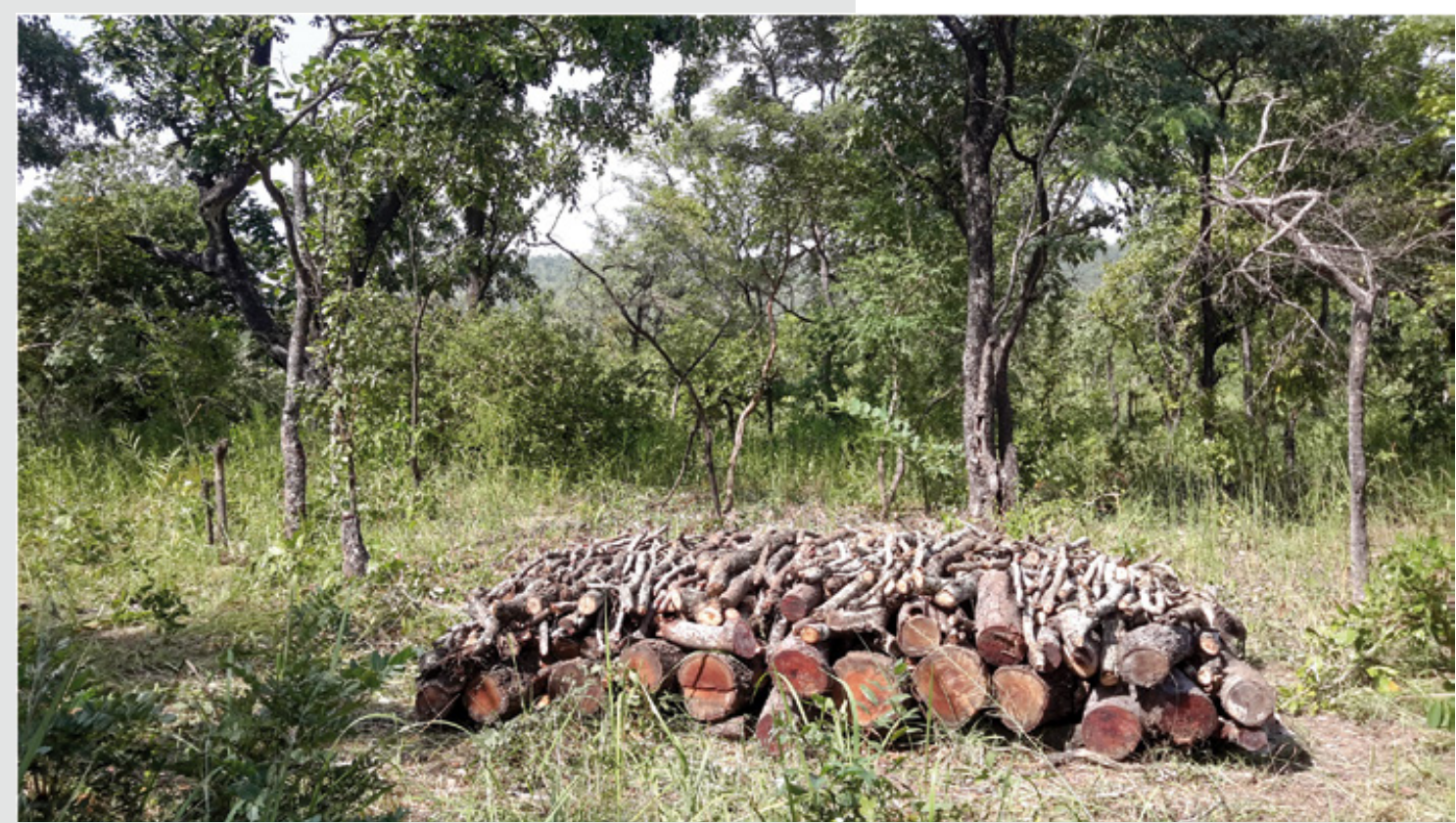

Photo 3.

Woody species used in charcoal production.

Photo J. D. T. Akpona. 


\section{Discussion}

This study aimed at establishing the first national TS inventory using multicriteria approach and setting priority for conservation in Benin. Our procedure for developing effective biodiversity conservation priorities of timber species in Benin was adapted from Magos Bhrem et al. (2010) and based on the availability of data information of local perceptions (UNEP, 1995). As many West African countries shared in a given degree the same timber species, we believe that it can be used or adapted to assist in species' prioritization and can also help in regional conservation of socio-economically important plant species. An active conservation of woody species is required, particularly timber species diversity, by establishing priority within species (Maxted et al., 2006). But effective strategies for biodiversity conservation (Maxted et al., 2006) has been developed using different methods. Our approach differs methodologically, from those used by Lawrence et al. (2005), Maraseni (2008), Vodouhe et al. (2009) and N'Danikou et al. (2011) who identified the most important Non-Timber Forest Products in Cameroun, Nepal, and Benin, respectively using community independent scoring in species value and conservation criteria. All these methodologies differ from the one used in this study and recently used by Idohou et al. (2013) because their findings were not based on the combination of criteria and in different methods. They argue on the importance of the use of the scoring method for studies of this type (N'Danikou et al., 2011). Brehm et al. (2010) argue that prioritization of species should be a dynamic process and multicriteria approach should be more relevant and criteria can change depending to the species or group of species considered (Idohou et al., 2013).
There were 24 timber species currently used in Benin. Much attention has historically been given to plant conservation (Codjia et al., 2003; Vodouhê et al., 2010; N'Danikou et al., 2011; Idohou et al., 2013; Yaoitcha et al., 2015; Sèwadé et al., 2016) and priority plant species have previously been suggested for conservation plans. These studies were related to crop wild relatives, wild edible plants and useful medicinal tree species.

Overall, 10 timber tree species were highlighted as priority for conservation in Benin. Among these species, K. senegalensis, K. grandifoliola, A. africana, M. excelsa, $P$. erinaceus appear as the top 5 priority species as available financial resources were not enough to conserve all species at once. Among the top 10 priorities species, 7 were protected under Benin Law 93.009 related to forest regime in Republic of Benin. This shows the importance of these species for conservation since 1993. Recent works from Yaoitcha et al. (2015) covering a single forest reserve, reported $A$. africana, $K$. senegalensis, $M$. excelsa, $P$. erinaceus, to be rare as perceived by local population around Wari-Maro forest reserve (Central Benin). Some other related works also revealed that prioritized species such as $K$. senegalensis, $P$. erinaceus and $M$. excelsa are threatened by overexploitation (Ouinsavi et al., 2005; Gaoué et al., 2007; Glèlè Kakaï et al., 2008; Bonou et al., 2009; Houehanou et al., 2013); which support their importance as priority species for active conservation. Three species ( $K$. senegalensis, $A$. africana and $P$. erinaceus) identified as priority for conservation were reported to be threatened in both open access and protected areas of Pendjari Biosphere Reserve of Benin (Houehanou et al., 2013). Besides it being a good lumber species, $M$. excelsa is also believed to

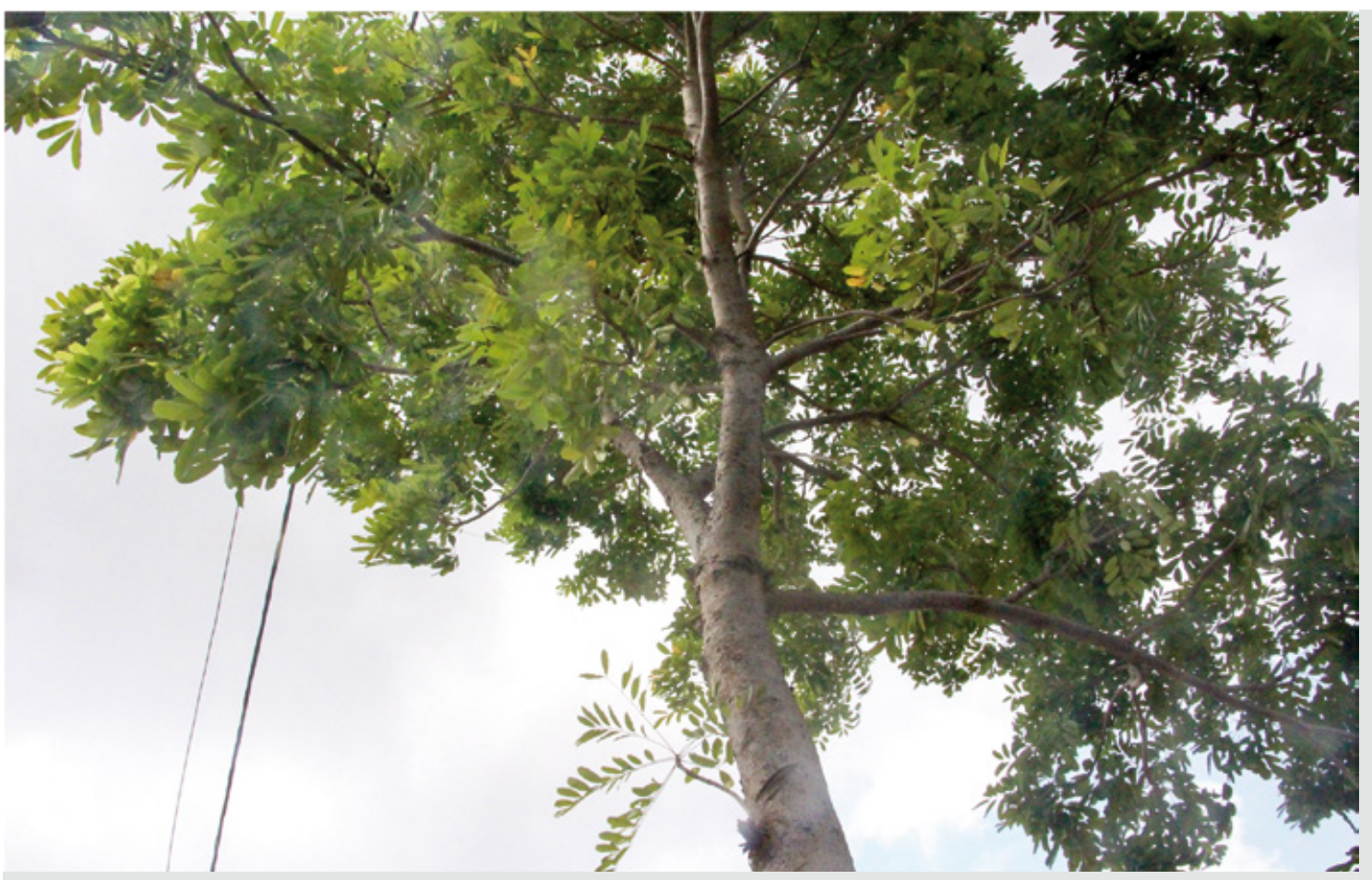

Photo 4.

Khaya senegalensis tree in urban area in Benin.

Photo J. D. T. Akpona. 


\section{References}

possess some diabolic powers, thus making it severely overexploited in Benin (Ouinsavi et al., 2005). To date, a detailed threat assessment using IUCN Red List Criteria has only been assessed for a few species (table IV), yet most species facing human harvesting pressure were often exposed to decline (Idohou et al., 2013). According to the IUCN Red List, P. erinaceus has not yet been evaluated but was evaluated in for Benin Red List (Adomou et al., 2011) as endangered, along with $A$. africana, $K$. senegalensis, $M$. excelsa. The last three species were identified as vulnerable on the international IUCN Red List. P. kotschyi used also as medicinal and animal feed plant, appears in the top 10 important timber species and was listed as a socio-economically important species that needs close attention regarding its current exploitation trends (Yaoitcha et al., 2015; Sèwadé et al., 2016).

Active conservation of TS in Benin should be a priority as the country occupies an important part in the "Dahomey Gap" (Akoègninou et al., 2006) who is a Savannah corridor separating the African rainforest into the western Guinea zone and the Central African Congo zone and where Biodiversity occur. Assuming the flora of Benin shares many species with that of other neighbouring countries covered by dense forests, then they may be facing the same problems because of the presence of similar timber species. The implications of this must be the implementation of trans-boundary strategies of conservation.

Many studies have previously been conducted on some of the identified priority species in Africa such as $P$. erinaceus (Ouédraogo et al., 2006; Nacoulma et al., 2011; Segla et al., 2016), A. africana and K. senegalensis (Gaoué et al., 2007; Traoré et al., 2011; Delvaux et al., 2009). All these studies have assessed population variations across ecological regions, the impact on population structure under different land use systems, viability of these species and proposed conservation strategies for their sustainable management and finally targeted sensitization of populations around habitats where the species occur to ensure conservation of these highly valued species. More attention should now be given to developing sylviculture packages for priority species.

\section{Conclusion}

This study highlights timber species diversity in Benin and yield substantial information on priority species for conservation and sylviculture. A total of 24 timber species were inventoried and most of them are used for medicine, food and charcoal. Ten species were selected as priority active conservation of these species requires allocating more effort for developing sylviculture packages and policy need to be developed to conserve the remains populations.

\section{Acknowledgments}

Funding for this project was provided by Rufford Foundation through grant $\mathrm{N}^{\circ} 14635-1$ provided to the first author. We are very grateful to the members of the Laboratoire de Biomathématiques et d'Estimations Forestières (University of Abomey-Calavi).
Adomou A. C., 2005. Vegetation patterns and environmental gradient in Benin: implications for biogeography and conservation. Ph.D. Thesis, Wageningen University, The Netherlands, $136 \mathrm{p}$.

Adomou A. C., Sinsin B., Akoègninou A. A., van der Maesen J., 2010. Plant species and ecosystems with high conservation priority in Benin. In: System Conservation African Plants, Eds van der Burgt X., van der Maesen J., Onana J-M., Royal Botanic Gardens, Kew, 429-444.

Adomou C. A., Agbani O. P., Sinsin B., 2011. Plantes. In: Protection de la nature en Afrique de l'Ouest: Une liste rouge pour le Bénin / Nature Conservation in West Africa: Red List for Benin, Eds Neuenschwander P. S., Sinsin B., Goergen G., International Institute of Tropical Agriculture, Ibadan, Nigeria, $365 \mathrm{p}$.

Albuquerque U. P., Medeiros P. M., Almeida A. L., Monteiro J. M., LinsNeto E. M. F., de Melo J. G., et al., 2007. Medicinal plants of the caatinga (semi-arid) vegetation of NE Brazil: a quantitative approach. Journal of Ethnopharmacology, 114: 325-354.

Amadé O., Adjima T., Karen Hahn-H., Sita G., 2006. Diagnostic de l'état de dégradation des peuplements de quatre espèces ligneuses en zone soudanienne du Burkina Faso. Science et changements planétaires / Sécheresse, 17 (4): 485-491.

Akoègninou A., van der Burg W. J., van derMaesen L. J. G., 2006. Flore Analytique du Bénin. Backhuys Publishers, Wageningen, $1034 \mathrm{p}$.

Bonou W., Glèlè Kakaï R., Assogbadjo A. E., Fonton H. N., Sinsin B., 2009. Characterisation of Afzelia africana Sm. habitat in the Lama Forest reserve of Benin. Forest Ecology and Management, 258: 1084-1092.

Codjia J. T. C., Assogbadjo A. E., Ekue M. R. M., 2003. Diversité et valorisation au niveau local des ressources végétales forestières alimentaires du Bénin. Cahiers d'Agricultures, 12, 321-331.

Dagnelie P., 1998. Statistiques théoriques et appliquées Tomes 1 et 2. Brussels, De Boeck et Larcier, 555 p. et 733 p.

Delvaux C., Sinsin B., Darchambeau F., Van Damme P., 2009. Recovery from bark harvesting of 12 medicinal tree species in Benin, West Africa. Journal of Apply Ecology, 46 (3): 703-712.

de Souza S., 2008. Flore du Bénin Tome 3. Nom des plantes dans les langues nationales béninoises. Cotonou, 679 p. 
Dimobe K., Wala K., Dourma M., Kiki M., Woegan Y., Folega F., et al., 2014. Disturbance and Population Structure of Plant Communities in the Wildlife Reserve of Oti-Mandouri in Togo (West Africa). Annual Research \& Review in Biology, 4 (15): 2501-2516.

FAO, 2009. Situation des forêts du monde. FAO, Rome, Italy, $43 \mathrm{p}$.

FAO, 2011. Situation des forêts du monde. FAO, Rome, Italy, $33 \mathrm{p}$.

Gaoue O.G., Ticktin T., 2007. Patterns of harvesting foliage and bark from the multipurpose tree Khaya senegalensis in Benin: Variation across ecological regions and its impacts on population structure. Biological Conservation, 137 (3): 424-436.

Glèlè Kakaï R. L., Sinsin B., Palm R., 2008. Étude dendrométrique de Pterocarpus erinaceus Poir. des formations naturelles de la zone soudanienne au Bénin. Agronomie Africaine, 20 (3): 245-255.

Glèlè Kakaï R., Sinsin B., 2009. Structural description of two Isoberlinia dominated vegetation types in the Wari-Maro Forest Reserve (Benin). South African Journal of Botany, 75: 43-51.

Gogan Y., 2010. Évaluation des espèces ligneuses actuelles et potentiellement candidates à l'exploitation forestière dans deux zones biogéographiques du Bénin : implication au reboisement et à la gestion durable des ressources forestières. Mémoire de licence, UCAO, 60 p.

Houehanou D. T., Assogbadjo A. E., Glèlè Kakaï R., Kyndt T., Sinsin B., 2013. How far a protected area contributes to conserve habitat species composition and population structure of endangered African tree species. Ecological Complexity, 13: 60-68.

Idohou R., Assogbadjo A. E., Fandohan B., Gouwakinnou G. N., Glélé Kakaï R. L., Sinsin B., et al., 2012. National inventory and prioritization of crop wild relatives: case study for Benin. Genetic Resources and Crop Evolution, 60: 1337-1352.

IUCN, 2015. The IUCN Red List of Threatened Species. Version 2015-4. http://www.iucnredlist.org (03/03/2016).

ITTO. 2007. Status of Tropical Forest Management 2005. International Tropical Timber Organization, Yokohama, Japan, $32 \mathrm{p}$.

Magos Brehm J. M., Maxted N., Martins-Loucao M. A., FordLloyd B. V., 2010. New approaches for establishing conservation priorities for socio-economically important plant species. Biodiversity Conservation, 19: 2715-2740.

Maxted N., Ford-Lloyd B. V., Hawkes J. G. (Eds), 1997. Plant genetic conservation: the in-situ approach. Springer, Chapman and Hall, London, UK, 446 p.

Maxted N., Kell S. P., 2009a. Establishment of a global network for the in-situ conservation of crop wild relatives: status and needs. FAO Consultancy Report, FAO, Rome, Italy, $265 \mathrm{p}$.

Maxted N., Kell S. P., 2009b. Commission on genetic resources for food and agriculture. Establishment of a global network for the in-situ conservation of crop wild relatives: status and needs. Background study, 39: 212 p.
Nacoulma B. M. I., Schumann K., Traoré S., Bernhardt-Römermann M., Hahn K., Wittig R., et al., 2011. Impacts of land-use on West African savanna vegetation: a comparison between protected and communal area in Burkina Faso. Biodiversity Conservation, 20 (14): 3341-3362.

N'danikou S., Achigan-Dako E., Wong J. L. G., 2011. Eliciting local values of wild edible plants in Southern Bénin to identify priority species for conservation. Economic Botany, 65 (4): 381-395.

Ouinsavi C., Sokpon N., Bada O., 2005. Utilization and traditional strategies of in situ conservation of iroko (Milicia excelsa Welw. C.C. Berg) in Benin. Forest Ecology and Management, 207: 341-350.

Putz F. E., 1991. Silvicultural effects of lianas. In: The Biology of Vines, Eds Putz F. E., Mooney H. A., Cambridge University Press, Cambridge, p. 493-501.

Rabinowitz D., Cairns S., Dillon T., 1986. Seven forms of rarity and their frequency in the flora of the British Isles, In: Conservation Biology: the science of scarcity and diversity, Soulé M. E. (Ed.). Sunderland: Sinauer Associates, p. 182-204.

Segla N. K., Habou R., Adjonou K., Mamoudou B. M., Saley K., Radji R. A., Kokutse A. D., Bationo A. B., Ali M., Kokou K., 2016. Population structure and minimum felling diameter of Pterocarpus erinaceus Poir. in arid and semi-arid climate zones of West Africa. South African Journal of Botany, 103: 17-24.

Sèwadé C., Azihou A. F., Fandohan A. B., Houéhanou T. D., Houinato M., 2016. Diversité, priorité pastorale et de conservation des ligneux fourragers des terres de parcours en zone soudano-guinéenne du Bénin. Biotechnologie, Agronomie, Société et Environnement, 20: 113-129.

Tabuti J. R. S., Muwanika V. B., Arinaitwe M. Z., Ticktin T., 2011. Conservation of priority woody species on farmlands: a case study from Nawaikoke sub-county, Uganda. Applied Geography, 31: 456-462.

Traore L., Ouedraogo I., Ouedraogo A., Thiombiano A., 2011. Perceptions, usages et vulnérabilité des ressources végétales ligneuses dans le Sud-Ouest du Burkina Faso. International Journal of Biological and Chemical Sciences, 5 (1): 258-278.

UNEP (United National Environment Programme), 1995. In: Global biodiversity assessment, Heywood (Ed.) Cambridge University Press, Cambridge, 1152 p.

Yaoitcha A. S., Houehanou T. D., Fandohan A. B., Houinato M. R. B., 2015. Prioritization of useful medicinal tree species for conservation in Wari-Maro Forest Reserve in Benin: A multivariate analysis approach. Forest Policy and Economics, 61: 135-146. 